\title{
Beyond belief? Pre-service teachers' perspectives on teaching RE in Ireland
}

\author{
Patricia Kieran $^{1} \cdot$ Aiveen Mullally ${ }^{2}$
}

Accepted: 7 September 2021 / Published online: 15 October 2021

(c) The Author(s) under exclusive licence to Australian Catholic University 2021

\begin{abstract}
This article overviews the contemporary context for teaching Religious Education (RE) in Ireland and profiles changing religious demographics in an increasingly secular context. It presents the findings of a two-year mixed-methods study undertaken in two third-level Catholic colleges in Ireland, investigating four hundred third-level Initial Teacher Education (ITE) students' perceptions of the religiously unaffiliated. The research data reveals the complexity and ambivalence of ITE students' attitudes to teaching RE in primary schools in a rapidly changing Irish society where one in ten is religiously unaffiliated (Central Statistics Office, 2017). Several challenges emerge for ITE students as they begin teaching RE in Ireland's denominational primary school context. The religious and convictional perspectives of the sample group are profiled and findings reveal that participants' personal worldviews impact on their understandings of their future professional roles as religious educators. Data from this mixed methods research suggest that while ITE students view the teaching of RE as an important professional duty, a disconnect between their own personal beliefs and the curricular content they are required to teach in sacramental RE programmes in Catholic primary schools creates a climate of ambivalence and uncertainty.
\end{abstract}

Keywords Religiously unaffiliated · Secular · Ireland · Initial teacher educators · Teaching religious education $\cdot$ Third-level colleges $\cdot$ Catholic

\section{The context for primary RE in Ireland}

Ireland is distinguished among most European countries at primary level, by its lack of a nation-wide system of state schools and the absence of a state Religious Education (RE) curriculum (Coolahan et al., 2012; Tuohy, 2013). Instead it has established a publicfunded system of largely private faith schools, each with their own distinctive curricula and approaches to RE or Ethical Education (Conboy, 2016; Faas et al, 2015; Hyland, 1993;

\footnotetext{
Patricia Kieran

patricia.kieran@mic.ul.ie

Aiveen Mullally

aiveen.mullally@mie.ie

1 Mary Immaculate College, University of Limerick, Limerick, Ireland

2 Marino Institute of Education, Dublin, Ireland
} 
Whittle, 2021). With the exception of a small number of multidenominational Community National Schools (Mullally, 2018), school patrons rather than the Department of Education and Skills (DES) have ultimate responsibility for the design, delivery and assessment of RE (Department of Education, 1999; Kieran \& Hession, 2005). Since education is mainly a church-state co-operative (Glendinning, 2012), 96\% of schools are denominational (DES, 2019) and the Government of Ireland Education Act (1998) affirms the rights of different church authorities to design and supervise the teaching of RE at primary level. While the Catholic Church is patron to $88.9 \%$ of primary schools; the Church of Ireland is patron to $5.5 \%$; and $4.8 \%$ have multi-denominational patrons with $0.8 \%$ categorised as 'other' (DES Statistical Bulletin Enrolments, 2019). In primary schools RE is one of seven curricular areas and the DES recommends a daily time allocation of $30 \mathrm{~min}$ for its teaching (Department of Education, 1999, 70). Importantly, parents and guardians have a legal right to withdraw children from RE (Government of Ireland, 1937; Department of Education, 1965; Department of Education, 1999) and schools are obliged to make alternative organisational arrangements for them (Department of Education, 1999, 58; Government of Ireland, Education (Admissions to Schools) Act, 2018).

\section{The teaching of RE}

For much of the twentieth century, religious education at primary level in Ireland was positioned exclusively within a denominational and overwhelmingly Christian framework (Lane, 2013). Up until the 1999 curriculum, the Department of Education assigned Religious Instruction (RI) a pre-eminent place and privileged status within the school curriculum. Historically, Catholic schools emphasised catechetical approaches aimed at faith transmission and evangelising through a 'learning into religion approach' (Lane, 2013, 27).

Writing in 1993, Drudy and Lynch noted the high status of religious communities in Ireland and the Church's role as the moral arbiters in society in the 'educational scene' (Drudy \& Lynch, 1993, 75). This is clearly no longer the case as the socio-cultural context has changed dramatically (Inglis, 1998, 2014; Lodge \& Lynch, 2004). There have been growing critiques of the existing denominational system (Nugent \& Donnelly, 2013; Park, 2019) and a re-evaluation of the adequacy of current approaches to RE (Dineen, 2021; Irwin, 2013; Scally, 2021). The growth of equality-based education (Hyland, 1989; NCCA, 2018; Educate Together, 2004; Conboy, 2016) has led to greater choice in educational provision through multidenominational Educate Together and Community National Schools and the government's proposal to introduce a new state-designed Education about Religion and Beliefs and Ethics (ERBE) programme (Coolahan et al., 2012; NCCA, 2020) has been met with both positive (O'Donnell, 2015) and negative responses (Conway, 2012; Van Nieuwenhove, 2012). Within Catholic schools an innovative Grow in Love programme has been rolled out (2015-2020) based on the 2015 Catholic RE curriculum (Irish Episcopal Conference, 2015). This invitational, child-centred, sacramental and confessional Grow in Love programme (Catholic School Partnership, 2015; Mahon \& O’Connell, 2015) was designed to meet the needs of a more secular and belief-diverse Ireland. While foregrounding the Catholic tradition, this RE programme emphasises the rights and dignity of learners, inter-religious learning and children's critical and higher order thinking (Byrne \& Kieran, 2013; Hession, 2015) while being 'utterly respectful of everyone's belief system' (Irish Episcopal Conference, 2010, 148). Finally, the changing demographic of pupils (Kennedy, 2021) and teachers in primary schools (Heinz et al., 2018) means that faith-based programmes may appear to be 
irrelevant or obsolete for those with no meaningful personal engagement with a religious tradition. Commenting on his own experience of schooling, Scally suggests that in recent decades, the low intellectual wattage surrounding Catholicism has condemned some RE teachers into providing a doomed sales pitch, with an air of apologetic insecurity, to students who can sense their lack of confidence and conviction (Scally, 2021).

\section{Contemporary challenges}

As the increasingly crowded primary school curriculum is being revised in Ireland (NCCA, 2020), the status and positioning of RE within the curriculum is being challenged (Meehan \& O'Connell, 2021; Kieran and Mc Donagh, 2021) and the state's proposed new workingtitle for the area consists of an awkward compound term 'Religious/Ethical/Multi-Belief Education-Patron's Programme' (NCCA, 2020). In addition, there is a lack of certainty about whether, how and when teachers might teach RE in primary schools. Research undertaken by the Irish National Teachers' Organisation (INTO, 2003) suggested that ten percent of teachers either did not teach or did not want to teach RE in primary classrooms. In Ireland, primary teachers are generalists and teach all seven curricular areas, yet a recent 2009 study in Catholic schools found that $28 \%$ of teachers did not teach RE on a daily basis as recommended, but only once a week, and 5.6\% rarely or never taught it (Dineen, 2009). As a consequence of mission and ethos dissonance in some Catholic schools (Dineen, 2021) there is a need for on-going teacher in-service to enable teachers to deliver effectively the Catholic RE programme (Meehan \& O'Connell, 2021; Kieran \& Mc Donagh, 2021) and to support inter-belief dialogue in Catholic schools (Kieran, 2019; Kieran \& Mullally, 2020; Mullally, 2019, 2021). Further, a longitudinal study on initial teacher education students has suggested that pre-service teachers may not intentionally teach RE according to curricular guidelines (O' Connell et al., 2018).

\section{The rise of the non-religious in Ireland}

In Ireland, between 1991 and 2016, the number of people ticking the 'No Religion' box in successive censuses, increased seven-fold (Central Statistics Office, 2017). Indeed, this category rose by $73.6 \%$ between 2011 when $5.9 \%$ of the total population stated they had 'No Religion', and 2016 with $9.8 \%$ identified with this category. Further, census data suggests that, among other reasons, age is an influential factor as $4.5 \%$ of 12 -year-old children were classified as having no religion, in contrast to $18.5 \%$ of 26 -year olds (Central Statistics Office, 2017). Despite this, the 2016 census results also reveal very high rates of religious self-identification in Ireland with $78.3 \%$ identifying as Catholic. However, those ticking the 'No Religion' box became the fastest growing category in the 2016 census and represented one-tenth of the overall population (Central Statistics Office, 2017). In this evolving context, the adequacy of Ireland's denominational primary school system to address the needs of a rapidly-growing secular society is a recurring theme in research literature (Hyland \& Bocking, 2015; Smyth et al., 2013). In 2018 the International Humanist and Ethical Union Report (IHEU) identified Ireland as one of the least favourable countries (115th out of 196) in recognising Atheist, Humanist and Non-Religious rights (IHEU, 2018). Further, Ganiel's research on post-Catholic Ireland highlights 'a shift in consciousness in which the institutional Catholic Church is no longer held in high esteem by many, including practising Catholics' (Ganiel, 2019, 479). This shift in consciousness may be attributed to increased internationalisation, 
the impact of clerical child sex-abuse (Jeffers, 2016; Parker-Jenkins, 2017; Scally, 2021), the fallout of the mother and child homes (Hogan, 2019), diversity of religion and belief (Faas et al., 2018a, 2018b; Kieran, 2019; Mullally, 2019), a highly educated population, as well as economic prosperity and secularisation (Ganiel, 2019). These factors have led to a questioning of former 'Catholic, White and Gaelic' identity markers (Heinz et al., 2018; ParkerJenkins \& Masterson, 2013) as well as a re-evaluation of the nature and position of RE in the school curriculum (Shanahan, 2017) where "private, mainly Catholic church control of the overwhelming majority of schools, is seemingly clashing head-on with the demands of an increasingly multi- and non-religious civil society' (Hyland \& Bocking, 2015, 252).

\section{Methodology}

The authors carried out a mixed methods study to understand how students taking the Professional Masters in Education programme (PME) in two Catholic teacher education colleges in Ireland perceive religious and non-religious families and students in Irish primary schools. Part one of the research survey profiled tertiary students' individual beliefs while part two explored their attitudes as future educators, to a belief diverse society, to religiously unaffiliated students and to teaching RE. The researchers focused on initial teacher education postgraduate students as many are older than their undergraduate counterparts with the possibility that some may have a richer life experience or an enhanced capacity for reflection and analysis. The research aimed to contribute to a greater understanding of key issues that might impact on these postgraduate ITE students' professional practice and on academic understandings of teaching RE to religiously unaffiliated children in Ireland. Since the Catholic educational system in Ireland at primary level operates within a transmissive model of faith formation (Irish Episcopal Conference, 2015), the research was designed to explore how ITE research participants described and understood their own beliefs as well as their perceptions of the beliefs of others in Ireland's multi-belief society.

This mixed methods study combined both quantitative (Teo, 2013) and qualitative (Cohen et al., 2018; Creswell \& Creswell, 2018) methods to elicit PME students' perspectives. The quantitative research instrument consisted of an anonymous online survey using the secure Survey Monkey package. This was deemed the most appropriate way to gather data from the participants who, due to Covid-19 restrictions, were engaging online in their teacher formation programme at the time of data collection. One can conjecture that students' daily online engagement may have contributed to the relatively high response rate to the survey (48\%). Two waves of the survey were carried out over two years (2020 and 2021) and opportunity sampling was employed as every PME student in both settings was invited to respond to the questionnaire.

Some of the questions and scales selected for the survey were drawn from the European Values Survey (2017) as well as McCarthy and Vitek's Going, Going, Gone: The Dynamics of Disaffiliation in Young Catholics study (2017) conducted in the USA. This enabled the researchers to compare and contrast relevant aspects of the gathered data with a much larger body of existing international research. The surveys gathered a large amount of both quantitative and qualitative data as survey comments boxes enabled respondents to elaborate upon some answers. $\mathrm{N}=400$ questionnaires were distributed and $\mathrm{n}=192$ questionnaires were returned (48\%). Further, after completing the voluntary survey, students were invited to self-select to participate in one-to-one semi-structured interviews. Again, due to Covid-19 restrictions, the five students who self-selected to participate in semi-structured interviews, were interviewed online. These in-depth interviews enabled the researchers 
to gather rich, more detailed and nuanced data on participants' beliefs and their perceptions of religiously unaffiliated students in primary schools as well as their own experience of teaching RE to date. Due to the sensitive and complex nature of researching personal beliefs and perspectives, the researchers were acutely aware of the potential for the research to uncover sensitive and difficult experiences (Allmark et al., 2009; Hays \& Singh, 2012). The ethical dimension of the research was foregrounded during research design and implementation and ethical clearance was gained in both institutions.

\section{Belief profile of participants}

Almost two-thirds of the participants were in the 18-34 years category (64\%) with a gender imbalance as $88 \%$ of participants self-identified as female. This reflects the reality of teacher education and the primary teaching profession in Ireland which is predominantly female (INTO, 2021). The urban-rural divide consisted of 52\% from rural areas and $48 \%$ from urban settings.

Part one of the survey profiled the beliefs of participants and reflected the denominational and overwhelmingly Catholic influence in Irish education. When it came to participants' own schooling, 97\% of the sample group had attended a Catholic primary school and $89 \%$ attended a Catholic post-primary school. Further $99 \%$ received the sacraments of First Eucharist and Confirmation. When asked if they now viewed themselves as belonging to a particular religious tradition or non-religious worldview, $80 \%$ responded in the affirmative, while $20 \%$ did not or did not know. Given that the sample group comes from a highly educated cohort of postgraduate university students it was interesting to note that one in five do not belong or do not know if they belong to a religious tradition or nonreligious worldview. This suggests that there may be a growing uncertainty or reluctance to identify with any one perspective or position.

When asked to tick what belief they identify with, 58\% signalled that they identify with Roman Catholicism, a further 7\% self-identify as Christian while 1\% are Church of Ireland and $1 \%$ are Christian Orthodox. The remaining 33\% identify with a range of worldviews including: Atheist (3\%); Agnostic (6\%); Free-thinker (2\%); Lapsed Catholic (5\%); Nonreligious (9\%); Spiritual (6\%) and Humanist (2\%) (Fig. 1).

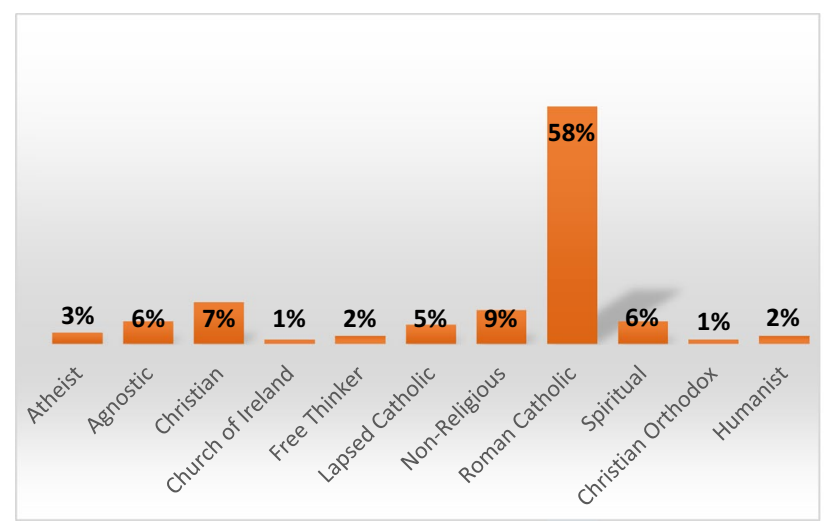

Fig. 1 Religious tradition or non-religious worldviews identified 
Question 10 asked those who identified with a particular religious tradition or nonreligious world-view how attached they were to it. Only $8 \%$ stated they were 'very strongly' attached, while $7 \%$ were very weakly attached to it. Overall, $58 \%$ were attached to their tradition moderately, rather weakly and very weakly. This suggests that overall, the sample group does not present as being very strongly attachment to their beliefs. Further, $28 \%$ stated they were weakly attached to their belief identity and $10 \%$ did not know. In successive survey questions the prevalence of a significant percentage who ticked the 'don't know' box was significant indicating perhaps that many were unsure how or reluctant to respond to questions and identify their own beliefs. When it came to their levels of attachment, only a small minority were very attached to their belief. Given Ireland's high level of religious self-identification in successive census results (Central Statistics Office, 2017), it may indicate a sense of the disruption with inherited loyalties and transgenerational identity (Murray, 2018). Moreover, while $99 \%$ of the participants received the sacraments of initiation within a confessional educational system designed to nurture faith (Irish Episcopal Conference, 2010; Mahon \& O'Connell, 2015; Pontifical Council for Promoting New Evangelisation, 2020), as adults one-third do not identify with the Christian tradition and classify themselves as belonging to a range of religiously unaffiliated worldviews. It is noteworthy also, that two-thirds (67\%) identify with the Christian tradition.

In the survey, participants were invited to tick a range of boxes indicating their current beliefs. As they were not limited to ticking only one box, the most prevalent beliefs came from $53 \%$ who identified with belief in souls, 53\% who believed in energy and $44 \%$ who believed in spirits. Of key significance is the fact that percentages of participants who believed in souls, energy and spirits exceeded percentages who believed in more traditional Christian beliefs such as belief in one God at 39\%, belief in the Holy Spirit at $37 \%$ and belief in angels at $40 \%$ (Fig. 2).

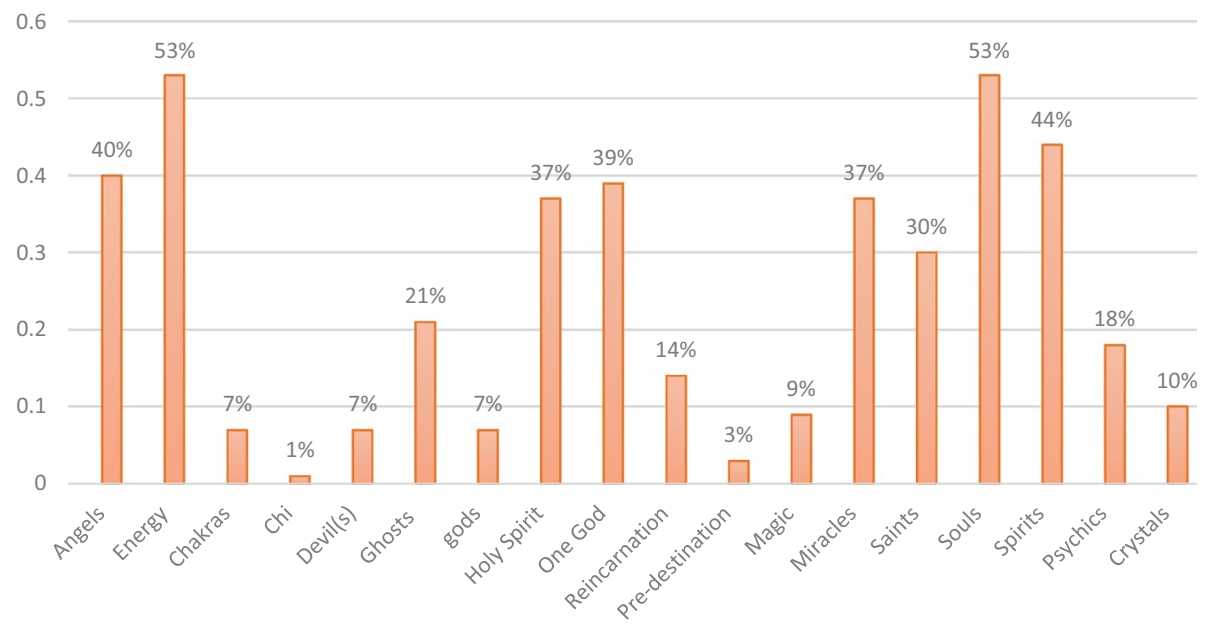

Fig. 2 Beliefs identified by participants 
As the overwhelming majority (89\%) of participants had experienced twelve years of primary and post-primary schooling in a Catholic context in Ireland, the data uncovers the breath of their beliefs which extends beyond orthodox Catholicism. Interestingly, $21 \%$ believe in ghosts, $18 \%$ believe in psychics, $10 \%$ believe in crystals and $7 \%$ believe in chakras.

Findings from Gladys Ganiel's research on religious practice in a post-Catholic Ireland (2019) indicates that people practice or identify with a range of eclectic and highly individual beliefs drawn from outside the formal ecclesial institution. Ganiel introduced the term 'Extra-Institutional Religion' to describe this phenomenon (Ganiel, 2019) and it helps to understand these ITE research participants' blending of a range of beliefs from diverse traditions. Nagle (2020) uses the term 'liquid modernity' when referring to the perceived trend of people moving beyond the boundaries of conventional ecclesial communities seeking extra-ecclesial experiences for their spiritual development. Further, Harmon's research on the voice of the child in RE in an Irish Catholic primary school, uncovers belief fluidity among children. His 'I am a Catholic Buddhist' research data shows that a significant number of children attending a Catholic school self-describing as belonging simultaneously to a variety of different traditions, without showing any sense of discomfort or contradiction (Harmon, 2018). Overall, existing research supports the initial findings of this current study on ITE students, which suggests that this cohort of ITE students are at ease with more nebulous, fluid beliefs which move beyond the boundaries of orthodox Catholicism while indicating participants' hesitancy be very committed to any one tradition.

In response to the question 'Do you ever attend religious services these days?', $16 \%$ attend once a week. 30\% replied 'never' and 29\% revealed seasonal attendance for holy days such as Christmas and Easter. For those who self-describe as Catholics (58\%), patterns of religious practice are considerably low (16\%) as weekly attendance at Mass is the minimum official requirement within the Catholic tradition. Obviously, practice of any religious tradition is highly complex and extends well beyond attendance at religious services, yet these findings raise questions regarding the appropriateness of expecting ITE students to assume the task of nurturing faith and teaching a catechetical RE programme in Catholic schools while simultaneously preparing children for the sacraments of First Penance, Eucharist and Confirmation (Kennedy, 2021). The data suggests the complexity and fragility surrounding the requirement that teachers teach a confessional RE programme that is at odds with their own pattern of religious practice or secular conviction. In a one-to-one interview participant $\mathrm{E}$ stated: 'I must admit I am not a very religious person myself and it was always a worry of mine that it may affect the children's learning in religious education. Over the past few years, I have stopped attending Mass, but I do still strongly believe in God'.

\section{Attitudes to teaching RE and non-religious beliefs in primary schools}

In the in-depth interviews, five ITE participants discussed their attitudes toward teaching RE in Catholic schools when on school placement. School placement forms a key part in ITE programmes (Teaching Council, 2020) and all research participants had 
experience of teaching RE to children in primary schools. Participant A commented: 'I go through the motions. People do go in and teach, even if they don't necessarily believe what they're teaching... if you want to teach in Ireland then its regardless of your own views'. This rupture between curricular content and personal conviction was a recurring theme. Participant $\mathrm{C}$ observed 'it is possible to engage with it (Catholic RE), and still be separate from it' while participant B said 'I find it a little bit false. It's just stuff they're just rattling off... I mean you would just have to do it if it was in the ethos of the school and you were in a Catholic school'. These comments reflect a professional bracketing of personal beliefs when teaching RE and a disconnect between participants' personal conviction and the task of teaching, especially in Catholic primary schools. As ITE students entrusted with the task of handing on the Catholic faith through a sacramental RE programme, the data uncovered the challenges this involves especially when onethird of participants' worldviews are secular and many others are religiously eclectic. Breda O'Brien notes that many pre-service teachers may have only experienced a thin, faded version of cultural Catholicism in their own education (O'Brien, 2019) and so the challenges they face when teaching RE in Catholic schools in Ireland should not be underestimated.

However, it is worth bearing in mind that the data also revealed that $72 \%$ of participants stated that they were comfortable teaching about a range of religious beliefs, when on school placement. One survey participant stated 'I believe I can teach RE to any child, giving lessons that allow for contemplative space in an open and accepting setting'. This statistic lowered when the survey question asked participants if they were comfortable teaching about non-religious beliefs when two-thirds or $66 \%$ replied in the affirmative (Fig. 3).

\section{DO YOU FEEL COMFORTABLE TEACHING ABOUT NON-RELIGIOUS BELIEFS?}

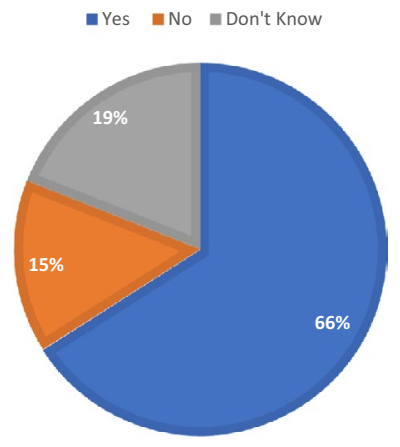

Fig. 3 Participant comfort levels teaching about non-religious beliefs 
One survey respondent elaborated in a comments box saying 'I may not know everything about every non-religious belief but I am confident in my ability to listen to those students and engage in my own research...communication, understanding, empathy and open discussions are more important than knowledge for education in this area'. Yet it is noteworthy that $34 \%$ of participants did not feel comfortable or did not know if they were comfortable teaching about non-religious beliefs. One survey participant stated 'I would not feel knowledgeable about non-religious traditions. I wouldn't know how to approach something like this' and another stated 'No, to be honest I don't even know what the term non-religious traditions means. I am not familiar with it at all'. Many respondents exhibited a sense of caution, ambivalence and reluctance, exemplified by one survey participant who stated they were fearful about teaching RE to children of different beliefs and with no religious beliefs as 'the last thing I'd want to do is upset any parents'.

When asked if they received adequate input from their ITE programme on teaching methodologies for teaching about non-religious beliefs in schools, 51\% either disagreed or didn't know. One respondent simply stated 'I would not know how to teach RE to children from non-religious traditions' (Fig. 4).

\section{WE WERE GIVEN ADEQUATE INPUT ON TEACHING METHODOLOGIES FOR TEACHING ABOUT NON-RELIGIOUS BELIEFS IN ITE}

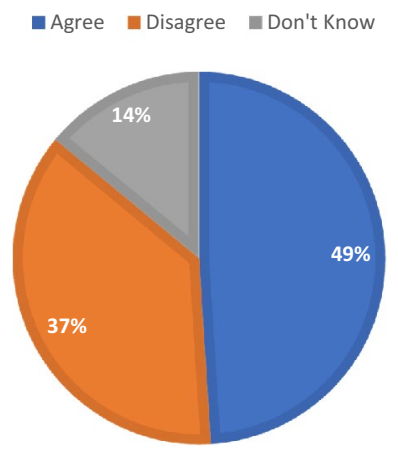

Fig. 4 Participants views on whether they received adequate input for teaching about non-religious beliefs 
Worryingly, over one-third (37\%) stated that they did not receive adequate input in their pre-service teacher education courses about how to teach the non-religious beliefs of the fastest growing category in the latest census data. This finding raises questions for ITE programmes concerning levels of understanding and preparation to teach RE in Ireland's increasingly diverse, secular context. Further, it suggests that much greater focus needs to be given, in ITE courses, on the complex worldviews and educational needs of atheist, agnostic, unbelieving, secular and unaffiliated children and their families.

\section{Recognition of children with no religious beliefs in primary schools}

A theme that emerged strongly from the data was participants' concern for the lack of recognition of children with no religious belief in Catholic primary schools in Ireland. In the one-to-one interviews participant E stated: 'For non-religious children on placement I was told to "let them do what they like" by my class teacher. I found this difficult as it went against what college had suggested regarding differentiated content'. Participant B had a similar experience:

'On placement when I first went to the teacher in a Catholic school, I asked her are there any other students in the class who don't do religion? She said yeah, that there are two. But she wouldn't tell me who they were and was just... "Oh, you know, one of them doesn't do it and the other one has no religion, but she kind of listens in". So, they were obviously in the class and I was teaching the Catholic religion, and I didn't know who they were. So, I was teaching the same stuff to everyone and I wasn't aware whether they were participating or not.'

This teacher's reluctance to acknowledge or discuss the individual children's learning needs increased the ITE participants' discomfort and was echoed by other responses to open questions in the survey. Another participant commented: 'Within Catholic schools it is expected to teach RE every day, but in this day and age there are many children who are non-religious, what do you do with the non-religious children when they do not believe in what you are teaching? Give them other work? Meaning excluding them from the class?'. Another participant observed: 'I have always found there's little guidance for children in Catholic schools who do not participate in Religion'.

Section 30.2(e) of the Education Act (1998) states that the Minister for Education is legally responsible for protecting the right of children not to attend any subject that is against their conscience. While parents have a constitutional right to withdraw their child from religious education and sacramental preparation in schools in Ireland (Education Admissions to School Act, 2018), these children often remain in the classroom during the teaching of RE in Catholic primary schools due to a lack of school resources and staffing to provide alternative educational supervision (Donoghue, 2021; Kitching, 2020; Mawhinney, 2006). The National Council for Curriculum and Assessment (NCCA, 2015) notes that schools should be flexible in making alternative arrangements for parents who opt their child out of the particular RE offered by a school. While diversity and inclusion are at the heart of a Catholic school (Mullally, 2019; CSP, 2015), many Catholic primary schools seem to leave it to the discretion of the individual class teacher to decide how to manage each child opted out of RE (Donoghue, 2021; McCarthy, 2021) indicating that opt-out procedures are ambiguous and insufficient. 


\section{Research implications}

The research raises significant questions about the professional expectations placed on ITE students regarding the teaching of RE. A significant number of the students' profiled in the research could not be classified as orthodox practicing Catholics. This may suggest that assumptions around their personal endorsement and willing delivery of a confessional RE programme in Catholic schools needs further examination. While the current Grow in Love catechetical programme has faith formation goals and is designed to initiate learners into the Catholic tradition (Irish Episcopal Conference, 2010), it is simultaneously an RE programme that fosters learning about and from the Catholic and other religious traditions. The aspect of sacramental preparation and faith formation in the RE programme for Catholic schools raises questions about whether it is appropriate or realistic to expect teachers to act as witness representatives (Kennedy, 2021) of believing communities in Ireland's increasingly secular context (Dineen \& Lundie, 2017; Cullen, 2019). There may be a mismatch between Ireland's denominational school system (95\%) and the lived experience and worldviews of a proportion of ITE students. The findings challenge the assumption that ITE students willingly engage in faith transmission when teaching RE and it raises questions about the adequacy of Ireland's denominational primary school sector to serve the needs of an increasingly secular society. Further, the data raises significant questions around the entitlement of children in Catholic schools to receive denominational RE in accordance with the teachings of the Catholic tradition.

The findings uncover the complex and eclectic nature of ITE students' personal beliefs and their 'Extra-Institutional Catholicism' (Ganiel, 2019). It highlights their range of attitudes toward teaching RE in Ireland's denominational school context. Further, the research suggests that much greater educational attention should be given to pre-service teachers' ambivalence and uncertainty surrounding the teaching of RE in primary classrooms. When it comes to teaching about non-religious beliefs, $37 \%$ reported being insufficiently prepared in their ITE programmes. Many participants expressed uncertainty about methodologies they might use. In addition, many ITE students expressed confusion around the implications of teaching RE in classrooms where some children are opted out of RE. Opting out should not mean the children are ignored or encouraged to do whatever they like in classrooms.

The data indicated a need for increased support and up-skilling for ITE students on how to dialogue with religiously unaffiliated children to enable them to provide inclusive RE in a denominational school context. Further, the data revealed the importance of nurturing inter-belief dialogue in all primary classrooms and equipping initial teacher educators with the dispositions and skills to feel confident and competent to create a safe, inclusive space to educate children about a range of religious and non-religious beliefs, especially in denominational settings (Kieran, 2013, 2019; Mullally, 2019, 2021).

\section{Conclusion}

The research has implications for primary schools in Ireland as the curriculum entrusts generalist teachers with the task of nurturing children's spiritual lives and teaching RE (O'Connell et al., 2018; O'Connell, 2018). The multiple challenges placed on ITE students when teaching RE in a denominational setting should not be underestimated. In recent 
decades the 'disorientingly rapid' (Hogan, 2019) socio-cultural revolution in Ireland means that there is a disconnect between the lived experience and worldview of many ITE students and the confessional and sacramental RE programme they are being asked to teach in Catholic primary schools. In a post-Catholic Ireland (Ganiel, 2019), reeling from the aftermath of clerical child-sex abuse, where many are grappling with Catholicism, unsure of church doctrine and uneasy about its effect on their lives (Scally, 2021), the once authoritative teachings of the Catholic Church are no longer adhered to (Inglis, 2017) by many ITE students. This raises serious issues for those teaching RE in Catholic primary schools and the research points to the need for greater input in ITE programmes on designing and delivering inclusive RE. In Catholic schools it indicates an urgent need to build on existing guidelines (CSP, 2015) and create a new framework to support teaching about religiously unaffiliated groups as well as teaching religiously unaffiliated children and supporting the rights of children withdrawn from RE. As ITE students begin to teach RE in denominational, mainly Catholic primary schools in Ireland, they have to negotiate a complex, evolving educational space with growing numbers of non-religious students. It is perhaps, unsurprising that many PME students are unsure of their own belief perspectives and feel ambivalent, hesitant and insecure when teaching confessional RE to others. Further, many also exhibit the features of fluid and extra-institutional understandings of what it means to be Catholic in contemporary Ireland.

\section{References}

Allmark, P., Boote, J., Chambers, E., Clarke, A., McDonnell, A., Thompson, A., \& Tod, A. M. (2009). Ethical issues in the use of in-depth interviews: Literature and discussion. Research Ethics Review, 5(2), 48-54.

Byrne, G., \& Kieran, P. (Eds.). (2013). Toward mutual ground: Pluralism, religious education and diversity in Irish schools. Columba Press.

Catholic Schools Partnership. (2015). Catholic primary schools in a changing ireland: sharing good practice on inclusion of all pupils. CSP.

Central Statistics Office. (2017). Census 2016 summary results-Part 1. Cork: Central Statistics Office.

Cohen, L., Manion, L., \& Morrison, K. (2018). Research methods in education (Eight). Routledge.

Conboy, S. (2016). The question of religious/belief diversity in Irish multidenominational primary schools. ETBI, 32-37.

Conway, E. (2012). The future of Catholic schools- the forum on patronage and pluralism: Cultural marker and wake-up call. The Furrow, 63(6), 369-177.

Coolahan, J., Hussey, C., \& Kilfeather, F. (2012). The forum on patronage and pluralism in the primary sector: Report of the forum's advisory group. Department of Education and Skills.

Creswell, J. W., \& Creswell, J. D. (2018). Research design: Qualitative, quantitative, and mixed methods approaches (5th ed.). Sage Publications.

Cullen, S. (2019). Turn up the volume: Hearing what the voices of young people are saying to religious education. In B. Gareth \& L. Francis (Eds.), Religion and educaiton: The voices of young people in Ireland (pp. 271-281). Veritas.

Department of Education. (1965). Rules for national schools under the department of education. The Stationery Office.

Department of Education. (1999). Primary school curriculum introduction. The Stationery Office.

DES. (2019). Statistical bulletin enrolments. Retrieved from: https://www.education.ie/en/Publications/ Statistics/Data-on-Individual-Schools/. Accessed 20 June 2020.

Dineen, F. (2009). Faith fully alive-O in the classroom? A critical exploration of primary school teachers' attitudes towards and experiences of the alive- $O$ religious education programme. Unpublished MA thesis. Mary Immaculate College, Limerick.

Dineen, F. (2021). Religious education in Catholic schools: Troubling times or routine ructions? In S. Whittle (Ed.), Irish and British reflections on Catholic education. Springer. 
Dineen, F., \& Lundie, D. (2017). Does religious education matter to teachers in Catholic primary schools? Concerns and challenges. In M. Shanahan (Eds.), Does religious education matter? (pp. 101-113). London: Routledge.

Drudy, S., \& Lynch, K. (1993). Schools and society in Ireland. Gill and Macmillan.

Educate Together. (2004). Learn together ethical education curriculum. Educate Together.

European values study. (2017). Retrieved from: https://europeanvaluesstudy.eu/. Accessed 4 Jan 2020.

Faas, D., Darmody, M., \& Sokolowska, B. (2015). Religious diversity in primary schools: Reflections from the republic of Ireland. British Journal of Religious Education, 38(1), 83-98.

Faas, D., Smith, A., \& Darmody, M. (2018). Between ethos and practice: Are Ireland's new multidenominational primary schools equal and inclusive? Compare: A Journal of Comparative and International Education, 49(4), 602-618.

Faas, D., Smith, A., \& Darmody, M. (2018). Children's agency in multi-belief settings: The case of community national schools in Ireland. Journal of Research in Childhood Education, 32(4), 486-500.

Ganiel, G. (2019). Religious practice in a post-Catholic Ireland: Towards a concept of 'extra-institutional religion. Social Compass, 66(4), 471-287.

Glendinning, D. (2012). Education and the law Haywards heath. Bloomsbury Professional.

Government of Ireland. (1937). Constitution of Ireland. Government Publications.

Government of Ireland. (1998). Education act. Government Publications.

Government of Ireland. (2018). Education (Admissions to Schools) Act. Retrieved from: http://www.irish statutebook.ie/eli/2018/act/14/enacted/en/print\#sec9. Accessed 8 July 2021.

Harmon, M. (2018). "I am a Catholic Buddhist": The voice of children on religion and religious education in an Irish Catholic primary school. Doctor of education thesis, Dublin City University.

Hays, D. G., \& Singh, A. A. (2012). Qualitative inquiry in clinical and educational settings. The Guilford Press.

Heinz, M., Davison, K., \& Keane, E. (2018). 'I will do it but religion is a very personal thing': Teacher education applicants' attitudes towards teaching religion in Ireland. European Journal of Teacher Education, 41(2), 232-245.

Hession, A. (2015). Catholic primary religious education in a pluralist environment. Veritas.

Hogan, C. (2019). Republic of shame: Stories from Ireland's institutions for 'fallen women.' Penguin.

Hyland, A. (1993). Educate together schools in the republic of Ireland. Fortnight Educational Trust.

Hyland, A. (1989). The multidenominational experience in the national school system in Ireland. Irish Educational Studies, 8, 89-114.

Hyland, A., \& Bocking, B. (2015). Religion, education, and religious education in Irish schools. Teaching Theology \& Religion, 18(3), 252-261.

Inglis, T. (2017). Church and culture in Catholic Ireland. Studies: An Irish Quarterly Review, 106(421), 21-30.

Inglis, T. (1998). Moral monopoly: The rise and fall of the Catholic church in modern Ireland. University College Dublin Press.

Inglis, T. (2014). Meanings of life in contemporary Ireland: webs of significance. Palgrave Macmillan.

International Humanist and Ethical Union. (2018). The freedom of thought report: A global report on the rights, legal status and discrimination against humanists, atheists and the non-religious. Retrieved from: https://fot.humanists.international/. Accessed 8 June 2021.

Irish national teachers' Organisation. (2003). Teaching religion in the primary school: Issues and challenges. INTO.

Irish Episcopal Conference. (2010). Share the good news. Veritas.

Irish Episcopal Conference. (2015). Catholic preschool and primary religious education curriculum for Ireland. Veritas.

Irish National Teachers' Organisation. (2021). The teaching profession 150 years on. INTO.

Irwin, J. (2013). Towards change: Exploring tensions in ethical-religious pedagogy in Irish primary education. In G. Byrne \& P. Kieran (Eds.), Toward mutual ground: Pluralism, religious education and diversity in Irish schools (pp. 177-186). Columba Press.

Jeffers, G. (2016). Telling tales-cruelty and abuse in schooling in Ireland. Education Research and Perspectives, 43, 101-136.

Kennedy, D. (2021). Encounters with truth: The hermeneutical task of religious education in the republic of Ireland. PhD Thesis. Dublin City University.

Kieran, P. (2013). Taking diversity of belief seriously in contemporary Ireland: The challenge for religious education in Irish schools. In G. Byrne \& P. Kieran (Eds.), Toward mutual ground: Pluralism, religious education and diversity in Irish schools (pp. 23-39). Columba Press.

Kieran, P. (Ed.). (2019). Connecting lives: Interbelief dialogue in contemporary Ireland. Veritas.

Kieran, P., \& Hession, A. (2005). Children catholicism and religious education. Veritas. 
Kieran, P., \& Mc Donagh, J. (2021). The centre cannot hold: Decolonising the RE curriculum in the republic of Ireland. British Journal of Religious Education, 43(1), 123-135.

Kieran, P. \& Mullally, A. (2020) 'The new 'nones': the implications of ticking the 'No Religion' census box for educators in Ireland' The Furrow, July/August, 387-395.

Kitching, K. (2020). Childhood, religion and school injustice. Cork University Press.

Lane, D. (2013). Religion and education: Re-imagining the relationship. Veritas.

Lodge, A., \& Lynch, K. (Eds.). (2004). Introduction. Diversity at school (pp. 1-6). Institute of Public Administration.

Mahon, E., \& O'Connell, D. (2015). Grow in love junior infants teacher's manual. Veritas.

Mawhinney, A. (2006). The opt-out clause: Imperfect protection for the right to freedom of religion in schools. Education Law Journal, 2, 102-115.

McCarthy, P. (2021). The experience of primary school teachers working in denominational schools with children from diverse religious and philosophical backgrounds who opt-out of religious education. Unpublished Masters Dissertation, Trinity College.

McCarthy, R. J., \& Vitek, J. M. (2017). Going, going, gone: The dynamics of disaffiliation in young Catholics. Minnesota: St Mary's Press.

Meehan, A., \& O'Connell, D. (2021). Religious education in Irish Catholic primary schools: Recent developments, challenges and opportunities. In S. Whittle (Ed.), Irish and British reflections on catholic education: Foundations, identity, leadership issues and religious education in Catholic schools (pp. 199-210). Springer.

Mullally, A. (2018). 'We are inclusive but are we being equal'?: Challenges to community national schools regarding religious diversity. Doctor of Education Thesis: Dublin City University.

Mullally, A. (2019). Guidelines on the inclusion of students of different beliefs in Catholic secondary schools. JMB.

Mullally, A. (2021). 'Why are Catholic schools afraid to be Catholic schools?' Challenges to leaders of Catholic secondary schools in Ireland. In G. Byrne \& S. Whittle (Eds.), Catholic education: A lifelong journey (pp. 247-260). Veritas.

Murray, P. D. (2018). Living Catholicity differently: On growing into the plenitudinous plurality of Catholic communion in god. In S. Hellemans \& P. Jonkers (Eds.), Envisioning futures for the Catholic church (pp. 109-158). Council for Research in Values and Philosophy.

Nagle, J. M. (2020). Out on waters: The religious life and learning of young Catholics beyond the church. Pickwick Publications.

NCCA. (2015). Education about religions and beliefs (ERB) and ethics in the primary school: Consultation paper. National Council for Curriculum and Assessment.

NCCA. (2018). Goodness me, goodness you: Third to sixth class. National Council for Curriculum and Assessment.

NCCA. (2020). Draft primary curriculum framework for consultation. National Council for Curriculum and Assessment.

Nugent, M., \& Donnelly, J. (2013). Only secular schools respect every person's human rights equally. In G. Byrne \& P. Kieran (Eds.), Toward mutual ground: Pluralism religious education and diversity in Irish schools (pp. 187-193). Columba.

O'Brien, B. (2019). Young people and the future of the Irish church. Studies: An Irish Quarterly Review, 108(430), 185-194.

O'Connell, D. (2018). Catholic primary schools—on rapidly thinning ice. The Furrow, 69(12), 660-670.

O'Connell, D, Ryan, D. C., \& Harmon, M. (2018). Will we have teachers for Catholic primary schools in Ireland? In S. Whittle (Ed.), Religious education in Catholic schools. Peter Lang.

O'Donnell, A. (Ed.). (2015). The inclusion delusion reflections on democracy ethos and education. Bern: Peter Lang.

O'Donoghue, S. (2021). 'It's no big deal': The perspectives and practices of primary school principals catering for children opted-out of religious instruction in Irish Catholic primary schools. Unpublished Masters Dissertation, Trinity College, Dublin.

Park, N. (2019). Why secular education is good for children, good for religion and good for society. In P. Kieran (Ed.), Connecting lives: Interbelief dialogue in contemporary Ireland (pp. 171-182). Veritas.

Parker-Jenkins, M., \& Masterson, M. (2013). No longer "Catholic, White and Gaelic": Schools in Ireland coming to terms with cultural diversity. Irish Educational Studies, 32(4), 477-492.

Parker-Jenkins, M. (2017). Spotlight on clerical sex abuse in Ireland: Human rights and child protection. International Journal of Law \& Education, 21, 41-55.

Pontifical Council for Promoting New Evangelisation. (2020). Directory for catechesis. Vatican.

Scally, D. (2021). The best Catholics in the world: The Irish, the church and the end of a special relationship. Sandycove. 
Shanahan, M. (Ed.). (2017). Does religious education matter? Routledge.

Smyth, E., Lyons, M., \& Darmody, M. (Eds.). (2013). Religious education in a multicultural Europe: Children parents and schools. Palgrave Macmillan.

Teaching Council. (2020). Céim: Standards for initial teacher education. The Teaching Council.

Teo, T. (Ed.). (2013). Handbook of quantitative methods for educational research. Springer.

Tuohy, D. (2013). Denominational education and politics: Ireland in a European context. Veritas.

Van Nieuwenhove, R. (2012). The end of Catholic education in Ireland: Further reflections on the forum on patronage and pluralism. The Furrow, 63(6), 278-285.

Whittle, S. (Ed.). (2021). Irish and British reflections on Catholic education. Springer.

Publisher's Note Springer Nature remains neutral with regard to jurisdictional claims in published maps and institutional affiliations. 